DOI : 10.31357/fapsmph.2015.00590

Morphological characterization and analysis of molecular mediated genetic variations in Anopheles subpictus s.l. (Diptera: Culicidae) in Sri Lanka

Dona Pamoda Wajirapanie Jayatunga-Katuwawalage

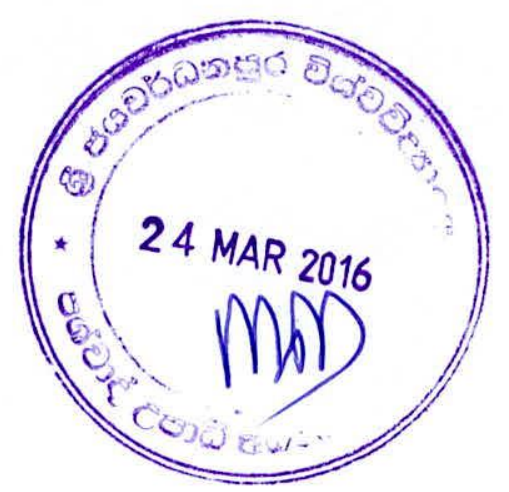

M.Phil. 
Morphological characterization and analysis of molecular mediated genetic variations in Anopheles subpictus s.l. (Diptera: Culicidae) in Sri Lanka

Dona Pamoda Wajirapanie Jayatunga-Katuwawalage

Thesis submitted to the University of Sri Jayewardenepura for the award of the Degree of Master of Philosophy in Zoology on $30^{\text {th }}$ of July 2015 


\section{Declaration by the candidate}

"The work described in this thesis was carried out by me under the supervision of Prof. B. G. D.

N. K. De Silva and Dr. N. V. Chandrasekharan and a report on this has not been submitted in whole or in part to any university or any other institution for another Degree/Diploma".

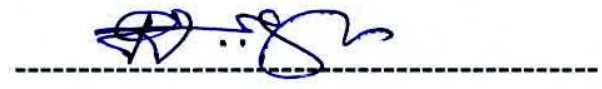

D. P. W. Jayatunga-Katuwawalage

We certify that the above declaration made by the condidate. is frue and accurate.

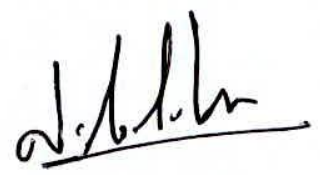

Prof.B.G.D.N.K. De Silva.
M. Chendractharan

Dr.N.V.Chandrasekharan. 


\section{Certification of supervisors}

We certify that the candidate has incorporated all corrections, additions and amendments recommended by the examiners.

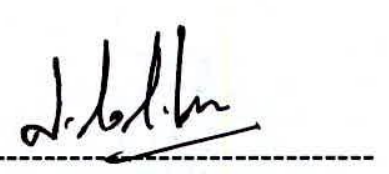

Prof. B. G. D. N. K. De Silva

Department of Zoology

Faculty of Applied Sciences

University of Sri Jayewardenepura

Sri Lanka

\section{3. $03 \cdot 2016$}

Date
M. Choundructhono

Dr. N. V. Chandrasekharan

Senior Lecturer

Department of Chemistry

Faculty of Science

University of Colombo

Sri Lanka
$23.03 \cdot 2016$

Date 


\section{TABLE OF CONTENTS}

Page no.

I. TABLE OF CONTENTS i

II. LIST OF TABLES ix

III. LIST OF FIGURES xii

IV. LIST OF ABBREVIATIONS xviii

V. ACKNOWLEDGEMENTS $\quad$ xxi

ABSTRACT $\quad$ xxiv

$\begin{array}{ll}1.0 \text { INTRODUCTION } & 1\end{array}$

$\begin{array}{ll}1.1 \text { Objectives } & 5\end{array}$

1.1.1 General objective 5

1.1.2 Specific objectives

2.0 LITERATURE REVIEW

$\begin{array}{lr}\text { 2.1 Mosquitoes } & 6\end{array}$

$\begin{array}{lr}\text { 2.2 Mosquitoes as disease vectors } & 8\end{array}$

$\begin{array}{ll}\text { 2.2.1 Malaria } & 8\end{array}$

2.2.1.1 Malaria in the globe $\quad 8$

2.2.1.2 Malaria situation in Sri Lanka $\quad 10$

2.2.1.3 Anopheline mosquitoes as malaria vectors $\quad 11$ 
2.3 Species complexes in mosquitoes

2.3.1 Sibling species and species complexes

2.3.2 Species concept

2.3.3 Genetics of speciation

2.3.4 Speciation genes

2.3.5 Cryptic divergence

19

2.4 Anopheline species complexes

2.5 An. subpictus species complex

2.7.2 Cuticular Hydrocarbon profiles

2.7.3 Cross breeding experiments (Hybridization studies) 
2.7.6.2 Diagnostic DNA probes $\quad 34$

2.7.6.3 Restriction Fragment Length Polymorphism (RFLP) 34

2.7.6.4 Amplified Fragment Length Polymorphism (AFLP) 35

2.7.6.5 Random Amplified Polymorphic DNA (RAPD) 35

2.7.6.6 Simple Tandem Repeats (STR) 36

2.7.6.7 Single Strand Conformation Polymorphism (SSCP) $\quad 37$

\section{$\begin{array}{ll}2.8 \text { Mosquito genomes } & 37\end{array}$}

2.8.1 Mitochondrial genome of mosquitoes 37

2.8.1.1 Mitochrondrial genome evolution 40

2.8.1.2 DNA barcoding 41

2.8.2 Nuclear genome of mosquitoes $\quad 43$

2.8.2.1 Multi-copy nuclear genes $\quad 45$

2.8.2.1.I Ribosomal DNA 45

2.8.2.1.I.I Internal Transcribed Spacer 2 (ITS2) 47

2.8.2.1.I.II D3 domain of $28 \mathrm{~S}$ gene $\quad 50$

2.8.2.2 Single copy nuclear genes (scnDNA) 51

2.8.2.2.I white gene $\quad 51$ 
2.9 Transient designations of sibling species status for An. subpictus within last fifty years 52

2.9.1 Morphological and cytotaxonomical studies 52

2.9.2 DNA-based studies

60

3.0 MATERIALS AND METHODS

3.1 Mosquito sampling and study population 62

3.2 Laboratory rearing of mosquitoes 63

3.3 Morphological characterization of different life stages of An. subpictus

3.3.1 Characterization of the sibling species using float ridge number of eggs

3.3.2 Characterization of the sibling species using mesothoracic seta 4 of fourth instar larvae

3.3.3 Characterization of the sibling species using seta 7-I of pupae

3.3.4 Characterization of the sibling species using adult female palpi 
3.4 Validation of standard taxonomic features in An. subpictus study Populations

3.5 Analysis of molecular mediated genetic variations 68

3.5.1 Study population $\quad 68$

3.5.2 Mosquito DNA (nuclear and mitochondrial) extraction 68

$\begin{array}{lll}\text { 3.5.3 PCR amplifications } & 69\end{array}$

3.5.3.1 Primer selection $\quad 69$

3.5.3.2 Optimization of PCR $\quad 70$

3.5.4 Agarose gel electrophoresis of PCR products 73

3.5.5 Purification of PCR products 73

3.5.6 DNA sequencing 73

3.5.7 DNA sequence analysis $\quad 74$

$\begin{array}{ll}\text { 3.5.8 Phylogenetic analyses } & 75\end{array}$

3.5.9 Constructing ITS2 secondary structures and determination of Compensatory Base Changes (CBCs) $\quad 76$

$\begin{array}{ll}\text { 4.0 RESULTS } & 77\end{array}$

4.1 Morphological characterization of An. subpictus 77

4.1.1 Characterization of An. subpictus sibling species by morphological features of life stages $\quad 77$

4.1.1.1 Eggs $\quad 77$

4.1.1.2 Larvae $\quad 78$ 
4.1.2 Validation of standard taxonomic features in An. subpictus study populations

\subsection{Determination of molecular mediated genetic variations}

4.2.1 Internal Transcribed Spacer 2 (ITS2)

4.2.1.1 PCR amplification of ITS2 95

4.2.1.2 ITS2 sequences 96

4.2.1.3 ITS2 sequence polymorphism

4.2.1.4 Phylogenetic analyses of ITS2 sequences

4.2.1.5 ITS2 secondary structures and analysis of Compensatory Base Changes (CBCs) 
4.2.3.1 PCR amplification of partial white gene

4.2.3.2 Partial white gene sequences

4.2.3.3 white gene polymorphism

4.2.3.4 Phylogenetic analyses of white gene sequences

4.2.4 Cytochrome $c$ Oxidase subunit 1 gene (COI)

4.2.4.1 PCR amplification of partial COI gene

4.2.4.2 Partial COI sequences

4.2.4.3 Analysis of polymorphism in $\mathrm{COI}$

4.2.4.4 COI phylogeny constructions

4.2.5 Cytochrome $b$ Oxidase gene $(C y t-b)$

4.2.5.1 PCR amplification of partial $C y t-b$

4.2.5.2 Partial $C y t-b$ gene sequences

4.2.5.3 Analysis of $C y t-b$ polymorphism

5.2 Molecular mediated genetic variations in An. subpictus s.l. in Sri Lanka 
5.3 Discrepancy on molecular taxonomy of An. subpictus Vs An. sundaicus

Appendix I- List of publications and communications

Appendix II- Specimens taken for analyses by DNA-based methods

Appendix III- General buffers, reagents and stock

solutions and instrumentation

Appendix IV-Software used for DNA sequence analyses

Appendix V- Raw ITS2 sequences, annotated ITS2 regions and ITS2 secondary structures in dot bracket notation 
Table 2.2 Morphological characters of An. subpictus sibling species

Table 2.3 Variations in wings and palpi recorded by Jude et al., 2014

Table 3.1 Optimized conditions for PCR amplifications

Table 4.1 Total number of engorged mosquitoes received for rearing and the number of successful iso-female progenies

Table 4.2 Morphological identification of sibling species status of oviposited adults, larvae and $F_{1}$ adults in six separate iso-female progenies from Puttalam

Table 4.3 Morphological identification of sibling species status of oviposited adults, larvae and $F_{1}$ adults in three separate iso-female progenies from Chilaw

Table 4.4 Morphological identification of sibling species status of oviposited adult, larvae, pupae and $F_{1}$ adults in thirty three separate iso-female progenies from Batticaloa 
Table 4.5 Morphological identification of sibling species status of oviposited adult, larvae, pupae and $F_{1}$ adults in thirteen separate iso-female progenies from Monaragala

Table 4.6 Morphological identification of sibling species status of larvae, pupae and $\mathrm{F}_{1}$ adults in the five separate isofemale progenies from Kurunegala

Table 4.7 Morphological identification of sibling species status of eggs, larvae, pupae and $\mathrm{F}_{1}$ adults in the single isofemale progeny from Monaragala

Table 4.8 Samples corresponding to ITS2 GenBank accession numbers of the present study 97

Table 4.9 Haplotypes of ITS2 detected by DnaSP

Table 4.10 Samples corresponding to the D3 GenBank accession numbers of the present study

Table 4.11 Haplotypes of D3 detected by DnaSP

Table 4.12 Samples corresponding to the white gene GenBank accession numbers of the present study

Table 4.13 Haplotypes of white detected by DnaSP

Table 4.14 Samples corresponding to the COI GenBank accession numbers of the present study

Table 4.15 Haplotypes of COI detected by DnaSP

Table 4.16 Samples corresponding to the $C y t-b$ GenBank accession numbers of the present study 
Table 4.19 A summary on molecular phylogenetic identification of samples

Table 4.19 Overall summary of DNA markers investigated from the present study and their parameters on genetic polymorphism detected using the software DnaSP 


\section{LIST OF FIGURES}

Page no.

$\begin{array}{lll}\text { Figure 2.1 Life cycle of mosquitoes } & 6\end{array}$

$\begin{array}{lll}\text { Figure 2.2 General morphology of a male mosquito } & 7\end{array}$

$\begin{array}{lll}\text { Figure 2.3 Distribution of world malaria } & 9\end{array}$

$\begin{array}{lll}\text { Figure 2.4 An. subpictus mosquito } & 24\end{array}$

Figure 2.5 Gene arrangement of mitochondrial genome of $A n$.

$\begin{array}{ll}\text { gambiae } & 38\end{array}$

$\begin{array}{lll}\text { Figure 2.6 rDNA cistron } & 47\end{array}$

Figure 2.7 An exemplary ITS2 secondary structure belonging to two species indicative of distinct hallmark features $\quad 49$

Figure 2.8 Polytene chromosome banding patterns of $A n$. subpictus sibling species A, B, C and D 53

Figure 2.9 Morphological differentiations of An. subpictus species complex $\quad 55$

$\begin{array}{lll}\text { Figure } 2.10 & \text { (a) Variations in palpi (b) Variations in wings } & 56\end{array}$

Figure 2.11 Pictorial representation of variations in palpi recorded by Jude et al., 2014

Figure 3.1 Map of Sri Lanka showing study areas: Monaragala, Kurunegala, Puttalam, Batticaloa and Chilaw 62

$\begin{array}{lll}\text { Figure } 3.2 & \text { Oviposition cup } & 63\end{array}$

$\begin{array}{lll}\text { Figure 3.3 Mosquito rearing basins } & 64\end{array}$ 
Figure 4.1 Float ridges in An. subpictus eggs

$\begin{array}{lll}\text { Figure } 4.2 \text { A hatched egg } & 78\end{array}$

Figure 4.3 Head and thorax of a typical An. subpictus larva 79

$\begin{array}{lll}\text { Figure 4.4 An. subpictus sibling species A larvae } & 80\end{array}$

$\begin{array}{lll}\text { Figure 4.5 An. subpictus sibling species B larvae } & 80\end{array}$

Figure 4.6 An. subpictus sibling species C larvae $\quad 81$

Figure 4.7 An. subpictus sibling species D larvae 81

$\begin{array}{lll}\text { Figure } 4.8 \quad \text { A typical pupal skin } & 82\end{array}$

$\begin{array}{lll}\text { Figure 4.9 Typical parts of an adult female } & 84\end{array}$

$\begin{array}{lll}\text { Figure 4.10 Typical tarsomeres of fore legs } & 84\end{array}$

$\begin{array}{lll}\text { Figure 4.11 Typical tarsomeres of hind legs } & 84\end{array}$

Figure 4.12 An. subpictus wing with spots made of dark and pale scales

Figure 4.13 Palpi of An. subpictus A with apical pale band longer than preapical dark band

Figure 4.14 Palpi of An. subpictus $\mathrm{B}$ with apical pale band shorter than preapical dark band

Figure 4.15 Palpi of An. subpictus $\mathrm{C}$ with apical pale band as same length as preapical dark band and the proboscis longer than palpi

Figure 4.16 Palpi of An. subpictus D with apical pale band as same length as preapical dark band and the proboscis as same length as palpi 
Figure 4.17 Mosquitoes of the same iso-female progeny having longer preapical dark bands as well as longer apical pale bands

Figure 4.18 Palpi with an additional dark patch present at the tips

Figure 4.19 Palpi with abnormally longer apical pale bands

Figure 4.20 Gel photograph showing agarose gel electrophoresis of PCR amplified 800 bp fragments of ITS2 for selected An. subpictus mosquito samples.

Figure 4.21 Multiple sequence alignment of ITS2 sequences

Figure 4.22 Haplotype network for ITS2 constructed by TCS v2.1

Figure 4.23 Phylogenetic tree for ITS2 sequences constructed using UPGMA method

Figure 4.24 Phylogenetic tree for ITS2 sequences constructed using NJ method

Figure 4.25 Phylogenetic tree for ITS2 sequences constructed using ML method

Figure 4.26 Phylogenetic tree for ITS2 sequences constructed using Bayesian Inference

Figure 4.27 A. ITS2 ML phylogeny for study generated sequences

B. ITS2 Bayesian phylogeny for study generated sequences

Figure 4.28 $\mathrm{CBC}$ table containing the calculated $\mathrm{CBC}$ counts for species An. subpictus, An. vagus and An. sundaicus

Figure 4.29 CBCs and hemi CBCs in An. subpictus A 
Figure 4.31 Gel photograph showing agarose gel electrophoresis of PCR amplified $500 \mathrm{bp}$ fragments of D3 for selected An. subpictus mosquito samples

Figure 4.32 Multiple sequence alignment of D3 sequences

Figure 4.33 Haplotype network for D3 constructed by TCS v2.1

Figure 4.34 Phylogenetic tree for D3 sequences constructed using UPGMA method

Figure 4.35 Phylogenetic tree for D3 sequences constructed using NJ method

Figure 4.36 Phylogenetic tree for D3 sequences constructed using ML method

Figure 4.37 Phylogenetic tree for D3 sequences constructed using Bayesian Inference

Figure 4.38 Gel photograph showing agarose gel electrophoresis of PCR amplified 800 bp fragments of white gene for selected An. subpictus mosquito samples

Figure 4.39 Multiple sequence alignment of white sequences

Figure 4.40 Haplotype network partial white gene constructed by TCS v 2.1

Figure 4.41 Phylogenetic tree for white gene sequences constructed using UPGMA method

Figure 4.42 Phylogenetic tree for white gene sequences constructed using NJ method 
Figure 4.43 Phylogenetic tree for white gene sequences constructed using ML method

Figure 4.44 Phylogenetic tree for white gene sequences constructed using Bayesian method

Figure 4.45 Gel photograph showing agarose gel electrophoresis of PCR amplified $600 \mathrm{bp}$ fragments of COI for selected An. subpictus mosquito samples

Figure 4.46 Multiple sequence alignment of $\mathrm{COI}$ sequences

Figure 4.47 Haplotype network for COI constructed by TCS v2.1

Figure 4.48 Phylogenetic tree for $\mathrm{COI}$ sequences constructed using UPGMA method

Figure 4.49 Phylogenetic tree for $\mathrm{COI}$ sequences constructed using NJ method

Figure 4.50 Phylogenetic tree for $\mathrm{COI}$ sequences constructed using ML method

Figure 4.51 Phylogenetic tree for $\mathrm{COI}$ sequences constructed using Bayesian method

Figure 4.52 Gel photograph showing agarose gel electrophoresis of PCR amplified 600 bp fragments of $C y t-b$ for selected An. subpictus mosquito samples

Figure 4.53 Multiple sequence alignment of $C y t-b$ sequences

Figure 4.54 Haplotype network for $C y t$ - $b$ constructed by TCS v2.1

Figure 4.55 Phylogenetic tree for $C y t-b$ sequences constructed using UPGMA method 
Figure 4.56 Phylogenetic tree for $C y t-b$ sequences constructed using $\mathrm{NJ}$ method

Figure 4.57 Phylogenetic tree for $C y t-b$ sequences constructed using ML method

Figure 4.58 Phylogenetic tree for $C y t$ - $b$ sequences constructed using Bayesian method 


\section{LIST OF ABBREVIATIONS}

\begin{tabular}{|c|c|}
\hline Adenine & $-A$ \\
\hline $\mathrm{ABC}$ & -ATP-Binding Cassette \\
\hline AFLP & - Amplified Fragment Length Polymorphism \\
\hline AMC & - Anti-Malaria Campaign \\
\hline BLAST & - Basic Local Alignment Search Tool \\
\hline BoLD & - Barcode of Life Database \\
\hline BSC & - Biological Species Concept \\
\hline bp & - base pair \\
\hline $\mathrm{C}$ & - Cytosine \\
\hline${ }^{\circ} \mathrm{C}$ & - Centigrade \\
\hline CBCs & - Compensatory Base Changes \\
\hline $\mathrm{CBHC}$ & - Cattle-Baited Hut Collection \\
\hline CBNC & - Cattle-Baited Net Collection \\
\hline $\mathrm{CHC}$ & - Cuticular Hydrocarbons \\
\hline $\mathrm{COI}$ & - Cytochrome $c$ Oxidase I \\
\hline CR & - Control region \\
\hline Cyt-b & - Cytochrome $b$ \\
\hline DDT & -Dichlorodiphenyltrichloroethane \\
\hline DNA & - Deoxyribo Nucleic Acid \\
\hline dNTP & - deoxynucleotides \\
\hline
\end{tabular}




\begin{tabular}{|c|c|}
\hline EtBr & - Ethidium Bromide \\
\hline G & -Guanine \\
\hline GC-MS & - Gas Chromatography-Mass Spectrometry \\
\hline HMM & - Hidden Markov Models \\
\hline HMS & -Hybrid Male Sterility \\
\hline ITS1 & - Internal Transcribed Spacer 1 \\
\hline ITS2 & - Internal Transcribed Spacer 2 \\
\hline $\mathrm{kb}$ & -kilo base pair \\
\hline $\mathrm{Mb}$ & - Mega base pair \\
\hline $\mathrm{MCMC}$ & - Markov Chain Monte Carlo \\
\hline ML & - Maximum Likelihood \\
\hline $\mathrm{mM}$ & -millimoles per liter \\
\hline mtDNA & - mitochondrial DNA \\
\hline NCBI & - National Center for Biotechnology Information \\
\hline ng & - nanogram \\
\hline NJ & - Neighbor-Joining \\
\hline NTS & - Non-Transcribed Spacer \\
\hline PCR & -Polymerase Chain Reaction \\
\hline RAPD & - Random Amplified Polymorphic DNA \\
\hline RFLP & - Restriction Fragment Length Polymorphism \\
\hline RNA & - Ribonucleic acid \\
\hline rpm & - resolutions per minute \\
\hline scnDNA & - single-copy nuclear DNA \\
\hline
\end{tabular}




\begin{tabular}{|c|c|}
\hline SNP & - Single Nucleotide Polymorphism \\
\hline SRF & - Spectral Repeat Finder \\
\hline SSCP & - Single Strand Conformation Polymorphism \\
\hline STR & - Simple Tandem Repeats \\
\hline $\mathrm{T}$ & -Thymine \\
\hline TEDHA & -Tropical and Environmental Disease \& Health Associates \\
\hline TROL & - Tandem Repeat Occurrence Locator \\
\hline ts & - transitions \\
\hline tv & - transversions \\
\hline $\mathrm{U}$ & - Uracil \\
\hline $\mathrm{U}$ & - Units \\
\hline UPGMA & - Unweighted Pair Group Method with Arithmetic Mean \\
\hline $\mathrm{V}$ & - Volt \\
\hline WHO & - World Health Organization \\
\hline$\mu \mathrm{g}$ & - microgram \\
\hline$\mu \mathrm{l}$ & - microliter \\
\hline
\end{tabular}




\section{ACKNOWLEDGEMENTS}

First and foremost, I am ever grateful to Prof. B. G. D. N. K. De Silva, University of Sri Jayewardenepura, Sri Lanka for granting me this opportunity to pursue this study at the University of Sri Jayewardenepura and for his remarkable guidance throughout the study period as a kind, patient and humble internal supervisor. I appreciate with gratitude, the financial support granted by him at certain stages, to make this research an achievable task.

I am indeed grateful to my external supervisor, Dr. N. V. Chandrasekharan, University of Colombo Sri Lanka, for his continuous guidance, useful comments and constant encouragements towards the completion of this study.

I would like to thank Dr. J. Weerasena at Institute of Biochemistry, Molecular Biology and Biotechnology (IBMBB), University of Colombo, Sri Lanka, for his valuable advices whenever I sought help.

My deep gratitude extends overseas to unseen pioneers of the field of bioinformatics as well. I take this opportunity to thank Prof. Joseph Felsenstein, at University of Washington, USA and Dr. Matthias Wolf, at University Wuerzburg, Germany, for their quick ready-tohelp responses and continual correspondence at my online requests to make the bioinformatics part of this study, a reality. 
I am very much grateful to Dr. C. Adikaram for her useful advices, comments, support and encouragements at my difficult moments as well towards the completion of this thesis.

I wish to acknowledge Dr. K. Ranatunga at Department of Zoology, University of Sri Jayewardenepura, Sri Lanka, for his valuable advices.

Ms. K. V. K. Gunathilaka at the Department of Zoology, University of Sri Jayewardenepura, Sri Lanka, too is gratefully remembered for her assistance in starting this study.

I wish to thank Entomological Assistants attached to the Anti-Malaria Campaign (AMC), Mr. M. A. S. T. Fernando of Tropical and Environmental Disease \& Health Associates (TEDHA) for providing me with mosquito specimens and Mr. N. Gomez of University of Sri Jayewardenepura, Sri Lanka, for arranging transportation for field visits on short term requests.

I wish to thank Ms. E. H. M.M. Hewadikaram, University of Sri Jayewardenepura, Sri Lanka, for all her support and useful comments at numerous occasions including mosquito specimen identifications.

I am thankful to my research colleagues at the Molecular Genetics Laboratory of University of Sri Jayewardenepura, Sri Lanka, Ms. Iresha Harischandra, Ms. P. D. 
Dayananda and Ms. H. S. Fernando for their useful comments and generous support for my work towards completion.

I wish to thank Prof. P. Manage, Head of the Department of Zoology, University of Sri Jayewardenepura, Sri Lanka and all other academic and non-academic staff members of the Department, especially Mr. A. Gunathunga for the kind support received during mosquito rearing.

I also wish to thank the staff members of the Faculty of Graduate Studies, University of Sri Jayewardenepura, Sri Lanka, especially Ms. S. Perera for her friendly administrative help throughout the study period.

I remind the financial support received from University of Sri Jayewardenepura under the grant ASP/06/RE/2010/018 and National Research Council under the grant 09-21 and Genetics Society, Department of Zoology, University of Sri Jayewardenepura.

Last but not least, I would like to thank my father, mother, brother, sister and my husband Oshadha Katuwawalage for being constant sources of encouragement, strength and patience in making this study a reality. If not for the technical support received from my brother and my husband, this would never have been achieved. 


\title{
Morphological characterization and analysis of molecular mediated genetic variations in Anopheles subpictus s.l. (Diptera: Culicidae) in

\author{
Sri Lanka
}

by

\section{Dona Pamoda Wajirapanie Jayatunga-Katuwawalage}

\begin{abstract}
Anopheles subpictus sensu lato is an important secondary vector of malaria in Sri Lanka. Literature based on morphology and cytology evidence An. subpictus to be a species complex consisting sibling species A, B, C and D. Recent molecular based studies carried out in Sri Lanka using Internal Transcribed Spacer 2 (ITS2) and Cytochrome $c$ Oxidase subunit-I (COI) gene have identified two sibling species, An. subpictus A and B. However, characterization of sibling species of An. subpictus using several molecular markers is yet to be established. Thus, objective of the present study was to determine validity of standard taxonomic keys based on mophomertry and identification of genetic variations in selected nuclear DNA markers and mitochondrial DNA markers among different populations of $A n$. subpictus s.l. in Sri Lanka. As the first step of the study morphometric features of larvae, pupae and adults of morphologically confirmed An. subpictus specimens which had been collected from five localities in the country were observed through laboratory rearing. In identification of molecular variations, five DNA loci (3 nuclear markers ITS2, D3, white gene and 2 mitochondrial DNA markers; $C O I$ and $C y t-b$ ) were subjected to PCR amplification and DNA sequencing. The resulted DNA sequences were analyzed using
\end{abstract}


modern bioinformatics tools and phylogenies of UPGMA, NJ, ML and Bayesian inference for each loci. Further, for ITS2, secondary structures were constructed and analyzed for the presence of Compensatory Base Changes.

Significant morphological variations were detected in standard morphometric features including larval mesothoracic seta 4 and adult palpi. Phylogenetic analyses of each DNA marker, together with two distinct ITS2 secondary structures confirmed the presence of two sibling species that corresponded to sibling species A and B. The two ITS2 secondary structures were found to have two $\mathrm{CBCs}$ each, denoting their reproductive isolation. Most importantly, in addition to $C O I$ and $C y t-b$ which inherent high mutation rates, low to moderate levels of polymorphism were detected in ITS2 and single-copy nuclear gene, white, in terms of many haplotypes. Present investigations highlighted that morphological characterization of An. subpictus using currently available standard morphometric characters was erroneous and hence could no longer be recommended as valid for $A n$. subpictus species identifications in Sri Lanka. Further, findings of current study confirmed the presence of two distinct sibling species A and B based on molecular mediated genetic variations of An. subpictus populations in Sri Lanka. Also, extent of polymorphism in ITS2 and white gene indicated the potential occurrence of more yet unexplained sibling species in An. subpictus species complex in Sri Lanka. Therefore, more intensive molecular characterization of the species from across the island should be undertaken to verify unknown members and also to determine present vector status of An. subpictus complex in Sri Lanka. 